\title{
Social Protection and Poverty Reduction in Four Selected Southeast Asian Countries: An Analysis of the Healthcare Sector towards Pro-Poor Growth
}

\author{
Senadjki Abdelhak \\ School of Social Sciences, Universiti Sains Malaysia USM \\ Minden 11800, Pulau Pinang, Malaysia \\ Tel: 60-12-429-0450Ｅ-mail: absenadjki@gmail.com \\ Jamalludin Sulaiman \\ School of Social Sciences, Universiti Sains Malaysia USM \\ Minden 11800, Pulau Pinang, Malaysia \\ Tel: 60-4-653-4618Ｅ-mail: jamals@usm.my
}

Received: September 21, 2011

Accepted: October 16, $2011 \quad$ Published: March 1, 2012

doi:10.5539/ass.v8n3p270

URL: http://dx.doi.org/10.5539/ass.v8n3p270

\begin{abstract}
This study explores key ideas needed in the current debate on the development of healthcare schemes and programs against poverty in four selected Southeast Asian countries; Vietnam, Indonesia, Thailand and the Philippines. It also traces the reasons why some of these countries have failed to achieve relative pro-poor growth through healthcare schemes. Using the poverty line of the four selected countries and Panel Data Analysis, the present study found that in Indonesia, Philippines and Vietnam, poor people do not benefit from the healthcare services provided by the government. In Vietnam the situation is even worse as the results showed that an increase in government expenditure on health led to increased poverty incidences. One of the possibilities for this to occur is that when government increases expenditure in healthcare sector, this causes a trade-off in other logistic sectors.
\end{abstract}

Keywords: Poverty, Poverty reduction, Social protection, Healthcare schemes, Panel data, Southeast Asia

\section{Introduction}

Southeast Asian Countries experienced an immense economic growth in the last two decades (Warr, 2002; Warr, 2000; Tambunan, 2005; Balisacan et al, 2003). The region has overcome the Asian financial crises of 1997 and witnessed remarkable economic growth since the year 2000; as a result of efficient economic and political policies which most of the countries have implemented. Political stability also played an important role in enhancing economic growth for most of the countries in the region (Singh, 2008).

Figure 1 illustrates the continuous GDP per capita growth in the four selected countries. The figure shows that the financial crisis of 1997 had a negative effect on GDP per capita, indicating a steady decline in four countries. Soon after, these countries recovered from the crisis and experienced continuous growth in GDP, indicating a sign of improvement in the standards of living of the region. The GDP per capita growth leads to the increase in the demand for goods and services (Pangestu, 2001), consequently leading to increasing job opportunities. This was very conspicuous, since most of the selected countries such Thailand and Vietnam, had reached a nadir rate of unemployment at 1.2; and 2.3 respectively (UN Database, 2010).

The growth in GDP per capita in the region led to the reduction of incidences of poverty, especially in Thailand and Vietnam as shown in Figure 2. Indonesia and Philippines seem to have been severely affected by the financial crisis since the incidence of poverty in these countries increased slightly after 1997. The achievement of economic growth and poverty reduction which the region attained was not consistent across the four countries. A comparison between Figure 1 and Figure 2 suggests that while Thailand and Vietnam achieved rapid economic growth which translated into dramatic decrease in the level of poverty incidences, Philippines did not 
perform well its economic growth; which clearly translated into the slow pace of poverty reduction. Philippines is slightly farther from achieving the Millennium Development Goal (MDG) by 2015. In Indonesia, even with the rapid growth in GDP per capita, the level of poverty incidence was again increased after the financial crisis.

Many studies have shown that poor peoples' income increase when the country experiences positive growth (Balisacan et al., 2003; Balisacan \& Pernia., 2002; Dollar \& Kraay, 2000; and Timmer, 1997). In this context, $\operatorname{OECD}(2009$, p.17) argued that:

"Poverty reduction depends on sustained and broad based growth, which in turn requires complementary initiatives which share economic benefits and promote better developmental outcomes for poor and excluded groups".

But a same kind of economic growth may lead to a range of poverty alleviation levels (Islam, 2004). Studies have found that economic growth was an incentive to increase people's income. This could substantially respond to poverty unless other aspects like sustainability and equity are achieved (OECD, 2009).

In Southeast Asian countries, a large number of poor and vulnerable people have not benefited from this growth (World Bank, 2006). Therefore, poverty alleviation is unachievable. Many factors: economic crisis, climate change, international trade and changes of commodities' prices could contribute for the failure of poverty eradication (Farrington, 2006). Disasters, environmental problems and other unforeseen circumstances may destroy households' capabilities, thus increasing their vulnerabilities. In this case, even though a country experiences rapid economic growth, tackling vulnerability and poverty become inefficient. Therefore, as shown in Figure 2, poverty remains a problem in Southeast Asia region. Cook (2009) stated that although the region experienced remarkable economic growth, it is not a sufficient condition which contributes to poverty reduction, since many others factors play important roles in determining peoples' wellbeing. At the same time, growth has been accompanied by a sharp increase in inequality across most countries in the region (Cook, 2009; Pangestu, 2001). This argument is supported by the study of Tambunan (2005), who found that in Indonesia, sustained poverty reduction required not only economic growth, but also a combination of many other factors such as the nature of the growth, improved access of the poor to markets, good education, health services, production assets, development of infrastructure, etc. In Thailand while low income groups did benefit from a rapid economic growth by high-wage employments, this growth has also produced social and environmental concerns such as inequality (Warr, 2002).

In Southeast Asia region a majority of the poor households live in rural areas and face various types of idiosyncratic and covariate risks such as disasters, unemployment, discrimination, lack of access to information, education, health, technology, market services and centers (Balisacan et al., 2005). Most of the poor are uninsured against these risks, leading them to implement informal strategies to cope, mitigate and manage against these risks (Balisacan et al., 2005), often causing them to become chronically poor (Fafchamps \& Lund, 2003; Bird \& Prowse, 2008; Gandhi et al., 2008). Therefore, there is a potential role for policies to play in tackling people's vulnerability and poverty. Poverty reduction cannot be efficiently alleviated if only governments, donors and NGOs implement and adopt strategies and programs which prevent the non-poor from falling into poverty trap and the poor to become chronically poor. Various development agencies such as World Bank (WB), Asian Development Bank (ADB) and Institutes of Development studies (IDS) have adopted social protection schemes and programs as strategies which could contribute in the achievement of the MDGs goals. These strategies and programs were found to play important roles in tackling poverty in developing countries (Mushunje \& Mafico, 2010; Barrientos, 2010; Kabeer, 2009; Nielsen et al., 2005; Kamerman, 2006; Begg \& Nectoux, 1995; Barrientos \& Hulme, 2008; Aswaf \& Jutting, 2007; Frota, 2008; Kaufman, 2007). These studies provide evidences to support that even social protection strategies can play a significant role in enhancing and supporting people to escape from poverty. However, most of the population and especially the poorest ones and rural dwellers have not benefited from these programs. Therefore, it was suggested that governments, donors and policy makers need to increase social protection schemes and programs to cover vulnerable areas and difficult environments where most poor people live.

From the previous discussions, there appears significant regional variation of poverty. It is well understood that economic growth is important in alleviating poverty. Figures 1 and 2 showed that, although Vietnam has the lower GDP per capita within the four selected countries, it has successfully eradicated poverty to lower levels. On the other hand, although Indonesia and Philippines have higher GDP per capita than Vietnam, poverty rate was still very high. From this observation, this article will argue that economic growth does not efficiently eradicate poverty, except the marginalized people who lack access to assets and services benefit from other strategies such as social protection, which insures them against uncertainties. Countries with well managed and 
efficient social protection programs could efficiently eradicate poverty. This study attempts to trace the reasons why some of the selected countries succeeded in alleviating poverty to lower rates through social protection strategies, whereas others failed to do so.

Salter (2006), Khamman (2009), Cook (2009) and Suharto (2007) gave an overview on social protection in Thailand and Southeast Asian countries respectively. Hutagalung et al (2009) investigated the problems and Challenges for the Indonesian Conditional-Cash Transfer Programme, while Dhanani and Islam (2002) investigated the impact of social protection strategies within a crisis period in Indonesia. Saidatulakmal (2009) gave an overview on social protection system in Malaysia. Others investigated how healthcare schemes promoted poor people in Southeast Asia countries (Ramesh \& Xun, 2008; Assan et al., 2009; Ensor and San, 1996; long, 2008; Adams, 2005; Jowett and Thompson, 1999; Heywood \& Choi, 2010; Manasan, 2009; Iwana, 2009; Arifianto, 2004; Ramesh, 2000; Asher, 2002; Thuan et al., 2006). These studies investigated social protection strategies theoretically, rather than empirically. Only few studies, such as van de wall (2003) have employed panel data process to highlight the link between Vietnam's social welfare transfers and poverty alleviation. Ensor and San (1996), using questionnaire also investigated the impact of healthcare schemes in Vietnam on poor households. These literatures are found to be exclusively based on single country studies. Studies carried out on ground of only single country analysis provided an understanding of social protection system in which particular country investigation of social protection programs' impact on poverty alleviation was hardly sufficient (Ramesh \&Xun, 2008). In contrast, pooled data analysis on the healthcare schemes and programs could enable the investigation with regards to why these programs succeed in alleviating poverty in some countries, whereas it failed in others.

No empirical study has investigated the role of healthcare schemes on poverty reduction in the four selected Southeast Asian countries, using pooled data to the best of our knowledge. Therefore, little is known about how healthcare schemes are able to insure non-poor people from escaping poverty traps or whether these strategies succeeded in moving the poor ones out of poverty in Southeast Asian countries. Similarly, the question of why some Southeast Asia countries succeeded in alleviating poverty than others, who attained a very slow pace of poverty reduction, was not well documented. To fill this gap, using panel data analysis from 1998 to 2006 and the national poverty line of the selected countries (Indonesia, Thailand, Philippine and Vietnam), this study investigated whether the social protection strategies (healthcare schemes in this case) for these countries succeeded in moving poor people out of poverty. It also traced reasons as to why some of these countries failed to achieve relative pro-poor growth, through social protection policies.

\section{Methodology}

The purpose of this study is to investigate the effect of health care schemes on poverty reduction. It aims to investigate the effect of healthcare schemes on poverty alleviation in the four selected Southeast Asia countries within the period 1998 to 2004 and 2006. The main objective of this study is to identify the reasons why there is significant improvement in poverty reduction through governmental social protection policies and practices in some Southeast Asian countries, whereas these same measures have failed in others. Since the present study attempts to investigate the effect of a strategy in each country on poverty reduction within the four selected countries, a pooled method is considered the appropriate tool which could provide an effective analysis, considering both the space (country) and time dimension (year) of the data. To fulfill the objective of the study, a simple model of government social protection expenditure (SPEx) influencing poverty (POV) was undertaken (Barrientos, 2010). In this model, poverty reduction is related to governmental social protection strategies as follows:

$(\mathrm{POV})=\mathrm{f}(\mathrm{SPEx})$

To model poverty exclusively as a function of various forms of health care expenditures is simply invalid. Moreover to distinguish between the social protection schemes effect and economic growth effect, GDP per capita variable is added to poverty equation. Thus the link between governmental social protection expenditure and poverty reduction is evaluated by using the following "social protection-poverty reduction" model:

$$
\mathrm{POV}=\mathrm{f}(\text { SPEx, GDPx }) \text {. }
$$

The model includes a series of variables identified from the literature as potential determinants of poverty reduction in developing countries and Southeast Asia (Cook, 2009; Saidatulakmal, 2009; Aswaf \& Jutting, 2007; kamerman et al., 2006; Nielsen et al, 2005; Barrientos, 2010; Frota, 2008;). The variables considered under "social protection-poverty reduction" model include: social protection expenditure on health (SPEH), measured as a percentage of General Government Expenditure; The health care expenditure (HCE), measured as a percentage of health care expenditure not financed by private households' out of pocket payments; and Social 
security expenditure on health (SSE), measured as a percentage of total health expenditure. Gross Domestic Product (GDP) per capita measured as the total annual output of a country's economy, here in current U.S. dollars per person. The dependent variable is poverty rate (POV), measured as the percentage of the population living below the poverty line for each selected country. Data of poverty rate was taken from different sources (Note 1). Data for poverty for years 1999 for Philippines; 2003 for Thailand; 1999, 2001, 2003 for Vietnam were calculated using the mean (i.e. poverty rate for year 1999 is equal to the poverty rate for year 1998 plus poverty rate for year 2000, all divided by two). Data for SPEH, HCE and SSE variable was taken from ILO database. Data for GDP variable was taken from Earthtrends database

By using Panel Data Analysis methods, Equation 2 could be written as follows:

$$
\mathrm{POV}_{\mathrm{xt}}=\beta_{0}+\beta_{1} \mathrm{SPEH}_{\mathrm{xt}}+\beta_{2} \mathrm{HCE}_{\mathrm{xt}}+\beta_{3} \mathrm{SSE}_{\mathrm{xt}}+\beta_{4} \mathrm{GDP}_{\mathrm{xt}}+\varepsilon .
$$

Where $\left(\beta_{\mathrm{i}}\right)$ indicates the parameters, $(\mathrm{x})$ the country and $(\mathrm{t})$ is time.

Choosing between the fixed and random effects (Note 2) in analyzing the pooled data, the Hausman test which is the most accepted tool was used. The results from Table A (appendix) rejects the null hypothesis and confirmed the alternative one (Note 3). Therefore, the fixed effects model was used to analyze the data set.

\section{How Do Healthcare Schemes Correlate With Poverty In Each Country?}

Table 1 summarizes the study's estimation results of the impact of social strategies on poverty incidence. The results showed that all the social protection variables are not statistically significant in Indonesia and Philippines, whereas these variables showed significant effect on poverty reduction in Thailand. Surprisingly, the results demonstrated that "government expenditure on health" variable is statistically significant at five percent level in Thailand and Vietnam, but the variable showed a positive sign in Vietnam. This means that in Thailand, every one percent increase in government expenditure on health, led to a decrease in poverty rate by 0.99 percent, whereas in Vietnam, every one percent increases in government expenditure on health led to the increase in poverty rate by 3.24 percent.

The results also showed that HCE variable was only statistically significant in Thailand at 5 percent level; the SSE variable was statistically significant at five percent level in both Thailand and Vietnam indicating the correct sign, while it was not statistically significant in both Indonesia and Philippines. GDP per capita remains key to poverty alleviation imitative. The findings demonstrated that GDP per capita variable was most important and had the correct sign at 5\% level of significance in Indonesia, Thailand and Vietnam. An USD1.00 increase in GDP per capita in Indonesia, Thailand and Vietnam led to a reduction in poverty rate by $0.006,0.011$ and 0.075 respectively. In meantime, GDP per capita has not shown any significant effect on poverty reduction in Philippines.

While the present study is aimed at examining healthcare cost's effect on poverty alleviation, it is also focused on addressing three variables related to healthcare costs and an unexamined the GDP per capita variable.

\section{Analysis of result and Discussion}

Why would the increase in social protection expenditure on health (SPEH) lead to increase in poverty rate in Vietnam? To answer this question, it is important to understand how the health sector in Vietnam performs. It is known that there exist large disparities between regions and income quintiles in Vietnam. Previous studies showed that rich people are the most likely to benefit from government services and the poor people appeared to pay more than the rich when they visit health facilities (Ensor \& San, 1996; Adams, 2005; Long, 2008). Edgeworth and Collins (2006) argued that the utilization of healthcare services is not likely to be maximized when only a small proportion of the population has access to these services. In the case of Vietnam, the small proportion of population is the rich people. Therefore, majority of poor households lacked access to public healthcare service, with most public healthcare services and hospitals serving rich people (Adam, 2005) (see Table B in appendix). Poor households are therefore, forced to use the private sectors as substitute. This leads to decline of household income and render households chronic poor (Russell, 2004, and Russell, 2005). Poor households spend more on healthcare and as such, the increase in their medical costs leads to a decrease in their capacities, which could in turn lead them to cut their consumptions and in some cases, to even sell their productive assets such as animals and land, in order to pay for the appropriate health facilities. Studies have found that sale of productive assets such as livestock served households to cope with unexpected stressors (Note 4). Equally it also led to serious poverty prevalence and made people unable to cope with future unpleasant events (Sauerborn et al 1996). This chain makes them more vulnerable and causes malnutrition, which may lead them to fall into chronic poverty again. Being inaccessible to public healthcare services and when they have the access, the poor quality of services and the high fees charged in Vietnam (Adams, 2005) exacerbate the poor 
people's situations. The sick people are not able to work for days and maybe longer, resulting in impoverished livelihood, as they are not able to generate income for their families.

From the previous analysis, it was shown that poor households who really need access to the various social protection schemes in Vietnam are disadvantaged. Therefore, the government's strategies were ineffective in providing equal healthcare services to her citizens. Many studies have shown that health care is an important player in eradicating poverty in developing countries. The results of the present study indicates that healthcare in Vietnam does not play an important role in tackling poverty, but more surprisingly, the figures illustrated that the increase in social protection expenditure on health increases the incidence of poverty rate in Vietnam. Even though the share of Government expenditure on health sector is very low in Vietnam compared to the other selected countries (Figure 3 in appendix); the increase in health expenditure still causes people to become poor. One of the possibilities for this to occur is that when government increases expenditure in healthcare sector, this causes a trade-off in other logistic sectors. This could be explained by the fact that decreased spending on other logistic sectors in such poor country, such as public goods, investment in productive sectors, education and/or agriculture, may decrease job opportunities to the poor people. Studies have also shown that the increase in spending on the agricultural sector in developing countries is one of the most important factors for promoting rural development and alleviating poverty in rural areas (Akroyd, 2007). In Vietnam, government investments in agricultural research significantly contribute to the alleviation of poverty incidence (Fan et al, 2004). Although the important role of the agricultural sector in promoting economic growth (agriculture contributed $20.4 \%$ of total GDP in 2005), creating jobs and income for the majority of the population, thus contributing in eradicating poverty in both rural and urban areas in Vietnam is recognized, the portion of total government expenditure allocated to this sector was only 5.5 percent compared to the Asian country average of 8.6 percent (Akroyd, 2007). The proportion of agricultural investment in total social investment decreased from 7.1 percent in 1996-1999 to 6.4 percent in 200-2003 (Huang \& Bocchi, 2009). The trade-off in investing in the productive sectors (such as agriculture) could reduce the production capacity and production quantity. In addition, the price of basic goods increases, leading to decreased purchasing power of households, thus making them poorer.

From the results, it is shown that in both Indonesia and the Philippines an increase in social protection expenditure on health (SPEH) did not significantly reduce poverty rate, while this increase in SPEH significantly reduced poverty rate in Thailand. In Thailand, government was the main player of public healthcare service provision and major financial contributor of healthcare sector (Note 5). Meanwhile, in both Indonesia and the Philippines, non-state people and institutions were major providers of public health service (Ramesh \& Xun, 2008) (Note 6). Therefore, government share is likely to play an important role in improving health sector services. This is clear because countries where the healthcare sector is dominated by the government in term of provision and financing (such as Thailand) were found to perform better than those countries where the health sector is dominated by the private sector (Ramesh \& Xun, 2008; and Long, 2008). However, since the poor are the most affected with risk of illness and have limited capacities, the distribution of public health care spending should be more to the poor quintiles. Only then could the government expenditure on health sector make significant progress in eradicating poverty.

Government provision and financing of the healthcare sector cannot be effectively successful in making the health sector to be more pro-poor except these efforts are combined with high management skills, resources and high skilled labour. Multidisciplinary management training leads to the improvement in hospitals performances (Supic et al., 2010).

High population also affects the efficiency of healthcare sector in both Indonesia and the Philippines, as a large proportion of the populations live in remote areas where many indigenous people live. A big proportion of those people are indigenous, living in rural area and facing high level of poverty and discriminations (IFAD, 2010). Assan et al (2009) found that as public spending on basic social services systematically discriminates the indigenous people who are found to be more likely poor than the non-indigenous ones; the access to health services and medicines is limited in indigenous communities of rural Indonesia. Additionally, high population causes higher number of people to face health problems (Note 7). The issue of the rapid pace of population growth in Indonesia and the Philippines causes the government a big burden in achieving an effective healthcare system. Even though these two countries have the highest population among the Southeast Asia countries, the respective governments allocated only six and seven percent respectively, of social protection expenditure on health from the total government expenditure, compared to Thailand which has lower population but allocated more than 16 percent of social protection expenditure on health from the government expenditure.

Other factor which could be the reason responsible for the inefficient performance in the healthcare sector in the Philippines and Indonesia is the challenge which the government face in the shift to decentralize the healthcare 
system. Both countries have not yet adopted the decentralization process (Lieberman, 2002). The decentralization system posed obstacles in the government's reorganizational of health sector in both the Philippines (Note 8) and Indonesia (Note 9). Few rules also guide the allocation of block grants between sectors and there are little guidelines regarding funding of different programs within the health sector (Michuad, 2010). There was even a significant increase in public funds for healthcare sector since the decentralisation occurred in 2001 (Note 10); although there has only been some improvement in the performance of health sector of Indonesia. This under performance in healthcare outcomes resulted due to the failure of leadership, politics as well as bureaucracy in the health sector (Heywood \& Choi, 2010). These observations are consistent to be found in Philippines. Studies have shown that one of the reasons for the insignificant performance of the healthcare sector in Philippines is due to the failure in the management of the different health programs implemented by the government such as Philhealth and Health Insurance Program (HIP). For example, studies showed that Philhealth program covered the rich people and was of disadvantage to the poor ones due to the inappropriate poverty targeting policies (Lagrada, 2010) (Note 11). Meanwhile, Thailand succeeded in covering all of her citizens with public health protection schemes (Note 12). A survey conducted by the National Statistic Office of Thailand in 2003 showed that over 60 percent of the beneficiaries of the Universal Coverage Schemes are the poorest citizens and only seven percent of the beneficiaries of this program are the rich. The Universal Coverage Scheme is one of the successful programs which contributed to the achievement of healthcare services coverage to the whole population.

When people are insured with various healthcare schemes and programs, they get easy access to healthcare and medical services. Therefore, they increase their utilization of these public health services, leading them to lower their out-of-pocket payments (and also reduce the risk of catastrophic expenditure for the poor citizens). In addition to reducing the costs of healthcare services, the healthy condition of the households (especially the poor ones) allows them to be more productive and generate more income, thus escaping poverty traps. It is reasonable to believe that the amount of spending on health sector is a good indicator for assessing the performance of the sector, therefore the contribution to the alleviation of poverty. However, this indicator can only be significant if the public spending reaches the poor and indigenous people who really need the healthcare services. Similarly, how the coverage is spread in those areas where the poor and indigenous people live plays an important role in making the health care sector to perform better.

The Philippines and Vietnam have the highest levels of households' private out-of-pocket payments, which accounted for over 83.7 and 90.2 percent in 2007 respectively. Meanwhile, Thailand and Indonesia have lower households' out-of-pocket payments on health expenditure, accounting for about 71.6 and 66.2 percent respectively (Note 13). The share of healthcare expenditure financed by the private out-of-pocket payment is relatively higher in Vietnam and the Philippines (which accounted for 60 and 50 percent of the total health expenditure respectively) than Thailand and Indonesia (which accounted for only 28 and 32 percent of the total health expenditure respectively) (see figure 4 in appendix). Although Indonesia has the lowest percentage of private out-of-pocket expenditure among the selected countries, the HCE variable was still not statistically significant in Indonesia, but was statistically significant at 5 percent level in Thailand. This results indicate that in Thailand due to the relatively high per capita GDP, households could afford to spend more on health, using their private out-of-pocket payment without it affecting their livelihood, while in Indonesia, households could not afford to spend too much on healthcare using their private out-of-pocket payment due to the relatively low per capita GDP (see figure 1 appendix).

The Philippines and Vietnam are heavily dependent on out-of-pocket payments in financing the healthcare sector. The households' payments on services in these two countries could cause a large poverty impact (Note 14). Studies showed that healthcare services could cause a regressive cost burden on households, especially in developing countries (Thuan et al, 2006). These costs could push poor people out from using healthcare services when they get sick; thereby deepening and exacerbating their health situation (Russel, 2004). The weak health situation of those households deters them from being productive and could cause them to lose their jobs, thereby pushing them into chronic poverty. Losses of income occur if the household experiences unexpected illness, especially if the ill person is a productive one (Thuan et al., 2006; Mondal et al., 2010; Van Doorslaer et al., 2006). These losses become catastrophic if the access to health services requires high out-of-pocket payments and the households have limited capacities to pay. Studies have shown that the quality of healthcare services, the frequency of illness of the households' members as well as the presence of a chronic illness on the breadwinner and hospitalizations are key factors which lead to catastrophic expenditure (Mondal et al., 2010)

Thailand has succeeded in financing the healthcare sector depending on her own public resources (Note 15). The government adjusted the share of out-of-pocket payments to its lower levels (Figure 4 in appendix), leading to 
the reduction in the burden of health care payments on household livelihoods. The highest percentage of private out-of-pocket payments in the Philippines and Vietnam and the high share of healthcare expenditure financed by the private out-of-pocket payments (see figure 4) are some of the main factors responsible for the failure of achieving significant performance in the healthcare sector in these two countries (Note 16). Therefore, providing access to healthcare services for people in countries with relatively low per capita GDP and high level of poverty only achieves sufficient performance when those poor people benefits from the facilities which make access to these services easy and accurate (Note 17).

The Vietnamese government was aware and recognized that in order to push the healthcare sector for better performance; it was necessary to provide poor people with access to the various healthcare services. To achieve this target, the government piloted the social health insurance (SHI) in 1989 (Note 18). From Table 1, the results show that an increase of one percent in social security expenditure (SSE) in Vietnam led to a decrease in the rate of poverty by 5.49 percent. A study by Evans et al (2006) showed that transfers effectively contributed to poverty eradication, as the poverty headcounts would have increased by 4.6 percentages if no social security transfers were received by the citizens. In both the Philippines and Indonesia however, the poor seem not to benefit from the social security schemes and programs as such, the result from Table 1 is not statistically significant for both countries.

Indonesia and Philippines failed to design an effective social health insurance scheme (Gertler \& Solon, 2002; Arifiano, 2004). Some of the failures noted in designing the social insurance programs in these two countries were the high administrative cost, coverage burden and inefficient management. The social insurance in Philippines failed to expand insurance coverage. Although poor people and particularly the poorest ones in Philippines benefited from the social welfare program which provided for them direct assistance in the form of cash, as well as other services including healthcare services, the coverage of social security and insurance programs is one of the lowest in the Southeast Asia region. The reason for the failure in expanding the social insurance coverage was due to the fact that the social insurance providers in both Indonesia and the Philippines were private providers whose sole purpose was for profit, like every other private company. In order to maximize their profits, private providers increased the price-cost margins to insured patients and by so doing, the out-of-pocket expenses of both the insured and uninsured patients became the same. This discouraged the uninsured patient to purchase insurance.

Low income Households' expenditure on healthcare services in Indonesia and the Philippines is very high compared to Thailand. In Indonesia, those who do not have access to public healthcare services spend more than 100 percent of their household income for one admission (Thabrany et al., 2003), whereas in Thailand, the universal coverage scheme has alleviated the burden of healthcare expenditure for poor people, which accounted for 7.56 percent of households' income in 1994 and fell to only 2.53 percent in 2006 (Iwana, 2009). In addition, the health insurance of unemployed people was introduced in Thailand after the financial crisis of 1997, which made a significant impact in improving unemployed people's livelihoods, thus contributing to poverty alleviation. Increase in the price-cost margins to insured patients in Indonesia and the Philippines led to increase in the burden on government. A study of the national objective for health in Philippines 2005-2010 explained two reasons as to why the share of social insurance to total health expenditure was relatively slow and cautious. The first reason was because PhilHealth was still in the process of improving its services; the benefits were very low. This led to discriminate the workers of the informal sectors.

The social security and insurance systems in the Philippines and Indonesia have the highest operating expenses of the total contribution in the region, which exceeded $15 \%$ in Philippines and $11.7 \%$ in Indonesia. Meanwhile in Thailand, Malaysia and Singapore, the operating expenses of the pension fund was only $3.9 \%, 2 \%$ and $0.5 \%$ respectively (Note 19) (Manasan, 2009; Asher, 2002). Therefore, improving the coverage areas, particularly to areas where the vulnerable and poor people live and enhancing the administrative and managerial skills is compulsory, in order to achieve robust and efficient social security and insurance health for the poor and the non poor as well. In addition, the social security expenditure on health sector will not achieve the objective of improving and enhancing the performance of the health sector and as such eradicate poverty, unless the healthcare services do not disadvantage the poor who really need access to these services.

\section{Conclusion}

This paper has identified the reasons why some of the four selected Southeast Asian countries succeeded in achieving the pro-poor growth through the healthcare schemes while others failed to do so. The analysis indicated that in Indonesia, Philippines and Vietnam, poor people do not benefit from the healthcare services provided by the government. In Vietnam in particular, the situation is even worse as the results showed that an 
increase in government expenditure on health led to increased poverty incidences. This is because the rich people benefited more from the public health services, whereas the poor ones are disadvantaged. An increase in government expenditure on healthcare services thus led to trade-off in spending in other logistic sectors such as the agricultural sector. Therefore, poor people, particularly, those landless in rural areas have limited access to employment opportunities impoverishing their livelihoods and making them poorer.

Government share is likely to play an important role in improving health sector services. The analysis indicated that countries where the healthcare sector is dominated by the government in terms of provision and financing (such as Thailand), were found to perform better than those countries where the health sector was dominated by private sector (i.e. Indonesia and Philippines). The analysis designated some of the key factors which obstinate the health care sector in Indonesia and Philippines. First, the high population in both countries affects the efficiency of healthcare sector, as a large proportion of the population live in remote areas where many indigenous people live. The high population causes higher number of people to face health problems. Secondly, a shift to decentralization system in the healthcare sector produced a big burden due to the lack of coordination and suitability in government structures and bodies, inadequate skills of district level staff and insufficient planning devoted to the process. Thirdly, the high share of healthcare expenditure financed by the private out-of-pocket payment in Vietnam and Philippines exacerbated poor livelihoods, particularly those who lack access to public healthcare services.

Social security and insurance are some of the important factors in achieving pro-poor growth in the healthcare sector. To achieve this target, the Vietnamese government piloted the social health insurance (SHI) in 1989. This program significantly contributed to the improvement of poor peoples' livelihoods, as it became the main provider of health services for the vulnerable and poor people. This action made a significant impact on eradicating poverty in Vietnam. However, Indonesia and the Philippines failed to design a social health insurance scheme. The social security system in Indonesia and the Philippines were found to be unsustainable and to disadvantage the poor who really need access to such programs. The analysis classified some of the reasons which caused the failures of designing social insurance programs in these two countries. The high administrative costs, coverage burden and inefficient management were found to be among the main factors which bound the social security schemes in Indonesia and the Philippines. Therefore, improving the coverage areas, particularly where the vulnerable and poor people live and enhancing the administrative and managerial skills is considered compulsory, in order to achieve robust and efficient social security and insurance health for both the poor and the non poor.

\section{Acknowledgement}

The main author wishes to thank Universiti Sains Malaysia for supporting with its USM fellowship to undertake this research. The usual disclaimer applies. Any remaining errors or omissions rest solely with the researchers of this work.

\section{References}

Adams, S. J. (2005, January). Vietnam's health care system: a macroeconomic perspective. Paper prepared for the international symposium on health care systems in Asia Hitotsubashi University, Tokyo. [Online] Available: www.imf.org/external/country/vnm/rr/sp/012105.pdf

Akroyd, S. (2007, January). Review of public spending to agriculture. A joint DFID / World Bank study. Oxford policy management. [Online] Available: www1.worldbank.org/publicsector/pe/pfma07/OPMReview.pdf

Arifianto, A. (2004, September). Social security reform in Indonesia: an analysis of the national social security bill (RUU Jamsosnas). Lambaga penelitian SMERU. [Online] Available: www.smeru.or.id/report/workpaper/jamsosnas/Jamsosnaseng.pdf

Asher, M. G. (2002). Southeast Asia's social security systems: Need for a system-wide perspective and professionalism. International Social Security Review, 55(4), 71-88. http://dx.doi.org/10.1111/1468-246X.00139

Asian Development Bank ABD. (2005, January). Poverty in the Philippines: income, assets, and access. Chapter Three: income poverty and inequality in the Philippines. [Online] Available: http://www.adb.org/documents/books/Poverty-in-the-Philippines/default.asp (May 28, 2010)

Assan, J.K., Assan, S.K., Assan, N. and Smith, L. (2009). Health inequality in resource poor environments and the pursuit of the MDGs: traditional versus modern healthcare in rural Indonesia. Journal of Health Management, 11(93), 93-108. http://dx.doi.org/10.1177/097206340901100107

Backman, G., Hunt, P., Khosla, R., Jaramillo-Strouss, C., Fikre, B., Rumble, C., Pevalin, D., Paez, D., Pineda, M., and Frisancho, A. (2006). Health system and the right to health: an assessment of 194 countries. The Lancet, 372 (9655), 2047-2085. http://dx.doi.org/10.1016/S0140-6736(08)61781-X 
Balagtas, A. (2010). PhilHealth benefits rich, not poor Filipinos DOH official. [Online] Available: http://www.gmanews.tv/story/184299/philhealth-benefits-rich-not-poor-filipinos-doh-official (September 20, 2010)

Balisacan, A.M., Edillon, R.G. and Piza, S.F.A. (2005). Rural poverty in Southeast Asia: issues, policies, and challenges. Asian Journal of Agriculture and Development, 2, 25-38. [Online] Available: http://www.searca.org/ajad/archives/v-02/01-02/ajad_v2_n1_n2_balisacan_etal.pdf

Balisacan, A.M., Pernia, E.M. and Strada, G.E.B. (2003). Economic growth and poverty reduction in Vietnam. ERD Working Paper No. 42. [Online] Available: www.adb.org/Documents/ERD/Working_Papers/WP042.pdf

Balisacan, Arsenio M. and Ernesto M. P. (2002). Probing beneath cross-national averages: poverty, inequality, and growth in the Philippines. ERD Working Paper Series No. 7. Manila: Asian Development Bank. [Online] Available:

http://www.adbdev.org/publications/probing-beneath-gross-national-averages-poverty-inequality-and-growth-ph ilippines

Barrientos A. and Hulme D. (2008). Social Protection for the Poor and Poorest in Developing Countries: Reflections on a Quiet Revolution. Brooks World Poverty Institutes BWPI Working Paper 30. [Online] Available: http:/www.bwpi.manchester.ac.uk/resources/Working-Papers/bwpi-wp-3008.pdf

Barrientos, A. (2010, January). Social protection and poverty. Social policy and development, Ment. Paper No. 42. [Online] Available: http://conselho.saude.gov.br/cm/artigos/Barrientos.pdf

Basri, M. (2010). Economic crisis and social protection in Indonesia. LPEM University of Indonesia. Gustav Papanek BIDE. [Online] Available: http://www.scribd.com/doc/30155745/Economic-Crisis-and-Social-Protection-in-Indonesia

Begg, I. and Nectoux, F. (1995). Social Protection and economic union. Journal of European Social Policy, 5, 285-302. http://dx.doi.org/10.1177/095892879500500402

Bird. K. and Prowse. M. (2008, April). Vulnerability, poverty and coping in Zimbabwe. World Institute for Development Economics Research [Online] Available: http://www.wider.unu.edu/publications/working-papers/research-papers/2008/en_GB/rp2008-41/

Chee, G., Borowitz, M. and Barraclough, A. (2009, September). Private sector health care in Indonesia. The United States Agency of International Development USAID. [Online] Available: http://pdf.usaid.gov/pdf_docs/PNADQ842.pdf

CIA Database Central Intelligence Agency. (2010). [Online] Available: https://www.cia.gov/library/publications/the-world-factbook/ (August 18, 2010)

Cook, S. (2009, May). Social protection in East and South East Asia: a regional review. SPA Working Papers. (Institute Of Development Studies, Brighton, UK). [Online] Available: http://www.socialprotectionasia.org/pdf/Sarah-Cook-SPA-WP02.pdf

Department of health Philippines. (2007). National Objectives for Health Philippines 2005-2010. Chapter 3: improving health system performance. [Online] Available: http://www2.doh.gov.ph/noh2007/ (August 15, 2010)

Dhanani, S. and Islam, I. (2002). Poverty, vulnerability and social protection in a period of crisis: the case of Indonesia. World Development, 30(7), 1211-1231. http://dx.doi.org/10.1016/S0305-750X(02)00028-1

Dollar, D. and Kraay, A. (2000). Growth is good for the Poor. Mimeo, World Bank, Washington. [Online] Available: http://www.worldbank.org/poverty.

Earthtrends database. (2010). Retrieved from www.earthtrends.org. Access on 20/05/2010

Edgeworth, R., and Collins, A.E. (2006). Self-Care as a response to diarrhea in rural Bangladesh: empowered choice or enforce adoption? Social Sciences and Medicine, 63(10), $2686-2697$. http://dx.doi.org/10.1016/j.socscimed.2006.06.022

Ensor, T. and San P. (1996). Access and payment for health by the poor in Northern Vietnam, International Journal of Health Planning and Management, $11(1)$, 69-84. http://dx.doi.org/10.1002/(SICI)1099-1751(199601)11:1<69::AID-HPM414>3.0.CO;2-P

Evans, M., Gough, I., Harkness, S., Mckay, A., Dao Thanh, H. and Do Le Thu, N. (2006). How progressive is social security in Viet Nam? Paper presented at the Social Security Workshop held jointly with the Ministry of Labour, Invalids and Social Affairs and the Viet Nam Academy of Social Sciences on 30th November 2006 in Ha No. [Online] Available: http://www.un.org.vn/index.php?option=com_docman\&task=doc_details\&gid=7

Fafchamps, M. and Lund, S. (2003). Risk sharing networks in rural Philippines. Journal of Development Economics, 7, 261-287. http://dx.doi.org/10.1016/S0304-3878(03)00029-4 
Fan, S., Lan Huong, P. and Quang Long, T. (2004, April). Government spending and poverty reduction in Vietnam. Project report prepared for the World Bank funded project "Pro-poor spending in Vietnam, by International Food Policy Research Institute, Washington DC, and Central Institute for Economic Management, Hanoi. [Online] Available: http://siteresources.worldbank.org/INTPRS1/Resources/383606-1106667815039/gov_spending_vietnam.pdf Farrington, J. (June, 2006). Growth and poverty in Asia: where next? Overseas Development Institute. Working Paper 267. [Online] Available: http://www.odi.org.uk/resources/download/621.pdf

Friedman, J., Hey Wood, P. F.., Marks, G., Saadah, F. and Choi, Y. (2006, January). Health sector decentralization and Indonesia's nutrition programs: Opportunities and challenges. Report No. 39690-IND. Health, Nutrition, and Population Unit, East Asia and Pacific Region. The International Bank for Reconstruction and Development, Washington, D.C, JANUARY 20, 2006. [Online] Available: http://www-wds.worldbank.org/servlet/main?menuPK=64187510\&pagePK=64193027\&piPK=64187937\&theSit ePK=523679\&entityID $=000020439 \_20070709143246$

Gandhi,V.J., Bantilan, C.S. and Parthasarathy, D. (2008, April). Vulnerability to HIV Risk in the Semiarid Tropics of Rural Andhra Pradesh. World Institute for Development Economics Research UNU-WIDER. [Online] Available: http://www.wider.unu.edu/publications/working-papers/research-papers/2008/en_GB/rp2008-49/

Gertler, P. and Solon, O. (2002, March). Who benefits from social health insurance? Evidence from Philippines. [Online] Available: http://faculty.haas.berkeley.edu/gertler/working_papers/gertler-solon\%20philippines\%20hopsital\%20paper\%203 -1-02.pdf

Heywood, P. and Choi, Y. (2010). Health system performance at the district level in Indonesia after decentralization. International Health and Human Rights, 10(3). http://dx.doi.org/10.1186/1472-698X-10-3

Huang, Y., and Bocchi, A.M. (2009). Reshaping Economic Geography in East Asia. Washington Dc, Word Bank. [Online] Available: http://www.usdrp-indonesia.org/files/downloadCategory/91.pdf

Hutagalung, S. A., Arif, S. and Suharyo, W. I. (2009, May). Problems and challenges for the Indonesian Conditional-Cash Transfer Programme - Program Keluarga Harapan (PKH). [Online] Available Social Protection Asia (SPA): http://www.socialprotectionasia.org/pdf/SMERU-SPA-WP04.pdf

ILO Database., Bureau of Library and Information Services. (2010). [Online] Available: http://www.ilo.org/declaration/lang--en/index.htm

International Fund for Agricultural Development IFAD. (2010). Rural poverty in Indonesia. [Online] Available: http://www.ruralpovertyportal.org/web/guest/country/home/tags/indonesia (August 25, 2010)

International Labour Organization ILO. (2010). Social security expenditure database. [Online] Available: http://www.ilo.org/dyn/sesame/IFPSES.SocialDBExp (March 24, 2010)

Islam, R. (2004, January). The nexus of economic growth, employment and poverty reduction: An empirical analysis. Issues in employment and poverty. Discussion Paper 14. [Online] Available: http://www.ilo.org/wcmsp5/groups/public/---ed_emp/documents/publication/wcms_120690.pdf

Iwana, R. (2009). Health security in Thailand: Can the universal coverage scheme be sustained in the current global economic crisis? 3rd China-ASEAN forum on social development and poverty reduction, 4th ASEAN +3 high-level seminar on poverty reduction, and Asia-wide regional high-level meeting on the impact of the global economic slowdown on poverty and sustainable development in Asia and the pacific. [Online] Available: www.adb.org/Documents/Events/2009/Poverty-Social-Development/papers.asp

Jowett, M. and Thompson, R. (1999, March). Paying for health care in Vietnam: extending voluntary health insurance coverage. Discussion Paper 167. Centre for health Economics. University of York. [Online] Available: http://www.york.ac.uk/media/che/documents/papers/discussionpapers/CHE\%20Discussion\%20Paper\%20167.pd $\mathrm{f}$

Kabeer, N. (2009, July). A review of social protection in South Asia. Social Protection Working Paper. [Online] Available:

http://www.unicef.org/socialpolicy/files/social_protection_in_south_asia_-_a_review_-_unicef_rosa_2009.pdf

Kaufman, R.R. (2007). Market Reform and Social Protection: Lessons from the Czech Republic, Hungary, and Poland. East European Politics and Societies, 21, 111-125. http://dx.doi.org/10.1177/0888325406297124

Khamman, S. (2009). Overviews of social protection: lesson learned from Thailand. NESDB, Thailand. [Online] Available: http://siteresources.worldbank.org/INTTHAILAND/Resources/OverviewSuwaneeKhamman1.pdf

Lagrada, L. P. (2010, April). Principles of Social Solidarity, Equity, Quality Assurance and Cost-Containment: PHIC enrollment, coverage and expenditures. Health Policy Development and Planning Bureau Department. 
[Online]

Available:

http://www.slideshare.net/healthfinancingsummit/2doh-transition-plan-to-achieve-mdg-4-5-032510-lzldoh

Lieberman, S.S. (2002). Decentralization and health in the Philippines and Indonesia: An Interim Report, Washington, DC: The World Bank. Available: http://www1.worldbank.org/publicsector/LearningProgram/Decentralization/decenhealth.pdf (August 6, 2010)

Long, G. T. (2008). Social health insurance in Vietnam: current issues and policy recommendations. Vietnam Development Forum (VDF) Tokyo. National Graduate Institute for Policy Studies (GRIPS). [Online] Available: http://www.ilo.org/public/english/region/asro/bangkok/events/sis/download/paper33.pdf

Manasan, R. G. (2009, August). Social insurance in the Philippines: responding to the global financial crisis and beyond. Philippines institute of development studies. Discussion paper series number 2009-23. [Online] Available: http://www3.pids.gov.ph/ris/dps/pidsdps0923.pdf

Michuad, C.M. (2010). External resource flows to the health sector in Indonesia. Annex B to the report flow of donor funds in Cambodia, Indonesia and Sri Lanka: synthesis of key finding. [Online] Available: http://www.who.int/macrohealth/documents/michaud_annexb.pdf

Mondal, S., Kanjilal, B., Peters, D.H. and Lucas, H. (2010). Catastrophic out-of-pocket payment for health care and its impact on households: Experience from West Bengal, India. Future health system. [Online] Available: http://www.gmanews.tv/story/184299/philhealth-benefits-rich-not-poor-filipinos-doh-official

Mushunje, M.T. and Mafico, M. (2010). Social protection for orphans and vulnerable children in Zimbabwe: The case for cash transfers. International Social Work. 53, 261-275. http://dx.doi.org/10.1177/0020872809355385

National Economic and Social Development Board Thailand. (2002). Thailand's official poverty line. [Online] Available: http://www.nscb.gov.ph/poverty/conference/papers/7_thai\%20official\%20poverty.pdf

National Objectives for HealthPhilippines, 2005-2010. (2005). Published by the Department of HealthSan Lazaro CompoundRizalAvenue, Santa CruzManila, Philippines October 2005. ISSN \# 1908-6768. [Online] Available: http://www.doh.gov.ph

Nielsen, I., Nyland, C., Smyth, R. and Zhu, C. (2005). Marketization and perceptions of social protection in china's cities. World Development, 33(11), 1759-1781. http://dx.doi.org/10.1016/j.worlddev.2005.05.007

OECD. (2009). Social protection, poverty reduction and pro-poor growth. Policy Guidance Note: Social Protection 17-39. [Online] Available: http://www.oecd.org/dataoecd/45/63/43573310.pdf

Pangestu, M. (2001). The social impact of globalization in Southeast Asia. OECD Development Centre. CD/DOC (2001)19. Working Paper No. 187. http://dx.doi.org/10.1787/603088241101

Ramesh, M. and Wu, Xun. (2008). Realigning public and private health care in Southeast Asia. The Pacific Review, 21(2), 171-187. http://dx.doi.org/10.1080/09512740801990238

Roselee, Shaharudin. and Fung, H. S. (2009). Does Size Really Matter? A Study of Size Effect and Macroeconomic Factors in Malaysian Stock Returns. International Research Journal of Finance and Economics, 24, 101-116. [Online] Available: http://www.eurojournals.com/irjfe_24_09.pdf

Russell, S. (2004). The economic burden of illness for household in developing countries: a review of studies focusing on malaria, tuberculosis, and human immunodeficiency virus/acquired immunodeficiency syndrome. American Society of Tropical Medicine and Hygiene, 71(2), 147-155. PMID: 15331831 [PubMed - indexed for MEDLINE]

Russell, S. (2005). Illuminating Cases: Understanding The Economic Burden Of Illness Through Case Study household research. Published by Oxford University Press in association with The London School of Hygiene and Tropical Medicine. http://dx.doi.org/10.1093/heapol/czi035

Saidatulakmal, M. (2009, October). Social protection in Malaysia. economic and social commission for western Asia (ESCWA). Arab Forum on Social Policy. Beirut, 28-29 October 2009. [Online] Available: http://css.escwa.org.lb/sdd/1035/SP_Malaysia_ver4.pdf

Sakunphanit, T. (2007). Universal healthcare coverage through pluralistic approaches: experience from Thailand. International labour organization ILO. Sub regional office for East Asia. [Online] Available: http://www.ilo.org/public/english/region/asro/bangkok/events/sis/download/paper31.pdf

Salter, B. (2006). Social Protection in Thailand: issues and options. ILO Sub regional Office for East Asia. [Online] Available: http://siteresources.worldbank.org/INTTHAILAND/Resources/OverviewBillSalter3.pdf

Singh, P. (2008, July). Social protection in ASEAN: issues and challenges for ASEAN and its member countries. Prepared For International Council On Social Welfare (ICSW).South East Asia and Pacific Region (SEAP). [Online] Available: http://www.icsw.org/doc/P2_Singh_Eng.ppt 
Suharto, E. (2007). Social protection systems in ASEAN: social policy in a comparative analysis. Presented at the 15th symposium of the international consortium for social development, The Hong Kong Polytechnic University, Hong Kong 16-20 July 2007. [Online] Available: http://www.policy.hu/suharto/Naskah\%20PDF/HongkongSocProASEAN.pdf

Supic, Z. T., Bjegovic, V., Marinkovic, J., Milicevic, M. S. and Vasic, V. (2010). Hospital management training and improvement in managerial skills: Serbian experience. Health Policy, 96, 80-89. http://dx.doi.org/10.1016/j.healthpol.2010.01.002

Tambunan, T. (2005). Economic growth, appropriate policies and poverty reduction in a developing country: some experience from Indonesia. South Asia Economic Journal, 6, 59-78. http://dx.doi.org/10.1177/139156140500600104

Tamsma, N. and Berman, P. C. (2004). The role of the health care sector in tackling poverty and social exclusion in Europe. The European health management association, EHMA. [Online] Available: http://www.ehma.org/files/EHMA\%20Poverty\%20Social\%20Exclusion\%20Report.pdf

Thabrany, H., Gani, A., Pujianto., Mayanda, L., Mahlil. and Budi, B. S. (2003, March). Social health insurance in Indonesia: current status and the plan for national health insurance (Annex 3). Center for Health Economic Studies, University of Indonesia, Presented in Social Health Insurance Workshop, WHO SEARO, New Delhi. [Online] Available: http://www.searo.who.int/LinkFiles/Social_Health_Insurance_an3.pdf

Thang, N., Trung, L.D., Dat, V.H. and Phuong, N.T. (2006, July). Poverty, Poverty Reduction and Poverty dynamics in Vietnam. Chronic poverty research center. [Online] Available: http://www.chronicpoverty.org/uploads/publication_files/CPR2_Background_Papers_Nguyen-Le_Dang-Vu_Ho ang.pdf

Thuan, N.T.B., Lofgren, C., Chuc, N.T.K., Janlert, U. and Lindholm, L. (2006). Households out of pocket for illness: evidence from Vietnam. Public Health, 6, 283. http://dx.doi.org/10.1186/1471-2458-6-283

Timmer, C.P. (1997). How Well Do The Poor Connect To The Growth Process? CAER Discussion Paper No. 17. Cambridge, MA: Harvard Institute for International Development.

UN Database. (2010). [Online] Available: http://Data.Un.Org/ Access On 20/05/2010

United Nations Economic and Social Commission for Asia and the Pacific (UNESCAP). (2007, March). Combat HIV/AIDS, malaria and other diseases. Bangkok, Thailand.

Van Doorslear, E., O’donnell, O., Rannan-Eliya., Somanathan, A., Adhikari, S.R., Akkazieva and B Garg, C.C. (2005). Paying out of pocket for healthcare in Asia: catastrophic and poverty impact. EQUITAP project, working paper No: 2. [Online] Available: http://www.eldis.org/assets/Docs/24169.html

Van Doorslear, E., O'donnell, O., Rannan-Eliya., Somanathan, A., Adhikari, S.R., Akkazieva, B and Garg, C. (2006). Effect of payment for healthcare on poverty estimates in 11 countries in Asia: an analysis of households' survey data. Lancet, 368, 1357-1364. PMID: 17046468 [PubMed - indexed for MEDLINE]

Warr, P. (2005, February). Road development and poverty reduction: The case of Lao PDR. ADB Institute Discussion Paper No. 25. [Online] Available: http://www.adbi.org/files/2005.02.dp25.poverty.roads.lao.pdf

Warr, P.G. (2000). Poverty incidence and economic growth in Southeast Asia. Journal of Asian Economics, 11, 431-441. http://dx.doi.org/10.1016/S1049-0078(00)00069-5

Warr, P.G. (2002). Poverty, inequality, and economic growth: The case of Thailand. Journal of Asian and African Studies, 37, 113-127. http://dx.doi.org/10.1177/002190960203700205

World Bank. (2006). Social protection in south Asia: growth with equity, security and opportunity. [Online] Available: http://go.worldbank.org/1Y1ZQIM4W0.

World Health Organization (WHO). (2010). World Health Statistics. [Online] Available: http://www.who.int/whosis/whostat/2010/en/index.html (September 19, 2010)

Notes

Note 1. National Economic and Social Development Board Thailand (2002, P.11); Basri (2010, P.5) Indonesia; ADB (2005, P.16); Economic Planning Unit Malaysia. War (2005, p.15); Thang et al (2006, P.9); CIA database; UN database and Earthtrends database.

Note 2. "Fixed effects model is chosen because we want to control for omitted variables that differ between cases but are constant over time. It allows us to use the changes in the variables over time to estimate the effects of the independent variables on dependent variable" (Roselee \& Fung, 2009, p.109).

Note 3. The null hypothesis states that the two estimation methods are both OK and therefore, that they should yield coefficients which are similar. The alternative hypothesis states that the fixed effects estimation is OK and 
the random effects estimation is not. In this case, then differences should be expected between the two sets of coefficients.

Note 4. Such as covering health care expenditures

Note 5. Thailand has the largest public hospitals care system in Southeast Asia. The public sector comprises about $80 \%$ of all hospital beds (Ramesh \& Xun, 2008).

Note 6. It was estimated that Philippines has the most privatized healthcare system in Southeast Asia region (Ramesh \& Xun, 2008). More than $53 \%$ of all the hospital beds and doctors are in the private sector (department of health, Philippines, 2007). It was also estimated that in Indonesia, over $67 \%$ of the suppliers of inpatient care are from the private sector (Chee et al., 2007).

Note 7. Indonesia accounted third worldwide highest number of cases of tuberculosis and more than $50 \%$ of healthcare disbursements in 2002 were allocated to HIV/AIDS, tuberculosis, malaria, child health and immunization (Michuad 2010). Tuberculosis is one of the main illnesses that causes of morbidity and mortality in the Philippines (UN, 2007).

Note 8. Lieberman $(2002, p .3)$ summarized these obstacles as, "1) opposition by health care staff who fear their loss of status; 2) benefits and authority as a result of being transferred to lower levels of government, 3) breakdown in staff deployment and other personnel mechanisms; 4) withdrawal of support previously earmarked for the poor, 6) lapses in reporting, accountability and quality control procedures, all potentially leading to deterioration in service delivery and quality".

Note 9. Meanwhile in Indonesia, the decentralization of the healthcare system faces many obstacles including the lack of coordination and suitability in government structures and bodies, inadequate skills of district level staff and insufficient planning devoted to the process (Friedman et al, 2006).

Note 10. Which was less than 0.5 of GDP between 1985 and 1999 (Heywood \& Choi, 2010) and increased to up to one percent in 2005 (Earthtrends database access 20 September 2010).

Note 11. Statistics show that in 2003, the richest people were benefited more than P5.2 billion from PhilHealth reimbursement, and the poor people benefited only about P1.4 billion (Lagrada, 2010).

Note 12. About $7 \%$ of the Thai populations are covered by Public Employee Benefit Schemes, $15 \%$ by Social Security Scheme and $76 \%$ covered by Universal Coverage Scheme (Sakunphanit, 2007)

Note 13. "Out-of-pocket Expenditure on Health is the direct outlays of households, including gratuities and in-kind payments made to health practitioners and to suppliers of pharmaceuticals, therapeutic appliances and other goods and services. This includes household direct payments to public and private providers of health care services, non-profit institutions, and non-reimbursable cost sharing, such as deductibles, copayments and fees for services" (WHO, 2010).

Note 14. In the Philippines, only the rich people who often have access to healthcare services can afford to purchase medicines. The middle income households may be negatively affected and impoverished to meet their out-of-pocket payments, where the hardcore poor do not even have pockets (Balagtas, 2010).

Note 15. The larger share of financing healthcare sector is reliance on taxation (Ramesh \& Xun, 2008).

Note 16. This observation is supported by Van Doorslaer et al (2005) and Van Doorslaer et al (2006), who argued that in countries where there are no exemptions of the poor from charges, the out-of-pocket payments still push many people to fall into the poverty trap. Long (2008) stated that the high medical costs and the high out-of-pocket spending in Vietnam are some of the critical causes that many eligible participants cannot access health care services. Backman et al (2006) found that even when households have access to health services; the high cost and fees associated with consultation and treatment disallow poor households to visit doctors, as it affects their income.

Note 17. Such as in Thailand which issued the health entitlement card

Note 18. This program enhances peoples' livelihoods, especially the vulnerable and poorer households. More than 30.5 million were covered by this program in 2006 in which about 11.2 million (or about 37 percent) were poor people (long 2008).

Note 19. Data for Philippines, Malaysia and Singapore for the year of 2007, data for Indonesia for the year 1996 and data for Thailand for the year 2000 


\section{Appendix}

Table A. Correlated Random Effects - Hausman Test

\begin{tabular}{lccc}
\hline Test Summary & Chi-Sq. Statistic & Chi-Sq. d.f. & Prob. \\
Cross-section random & 42.323795 & 6 & 0.0000
\end{tabular}

Table B. Spending on public health, from poor to rich in Vietnam

\begin{tabular}{|c|c|c|c|c|c|c|c|}
\hline Quintile & \multicolumn{2}{|c|}{ Government hospital } & \multicolumn{2}{c|}{ Commune facilities } & All \\
\hline & $\begin{array}{c}\text { Percent } \\
\text { of annual } \\
\text { visits }\end{array}$ & $\begin{array}{c}\text { Public } \\
\text { spending } \\
\text { per visit }\end{array}$ & $\begin{array}{c}\text { Percent } \\
\text { of public } \\
\text { spending }\end{array}$ & $\begin{array}{c}\text { Percent } \\
\text { of annual } \\
\text { visits }\end{array}$ & $\begin{array}{c}\text { Public } \\
\text { spending } \\
\text { per visit }\end{array}$ & $\begin{array}{c}\text { Percent of } \\
\text { public } \\
\text { spending }\end{array}$ & $\begin{array}{c}\text { Percent } \\
\text { of public } \\
\text { spending }\end{array}$ \\
\hline Poorest & 10.9 & 9838 & 10.7 & 25.5 & 1118 & 24.4 & 13.5 \\
\hline Near poorest & 15.2 & 7440 & 15.3 & 24.2 & 943 & 24.2 & 17.3 \\
\hline Middle & 19.9 & 6982 & 20.2 & 20.5 & 922 & 20.6 & 30.3 \\
\hline Near richest & 24.8 & 6963 & 22.4 & 19.3 & 937 & 19.6 & 21.9 \\
\hline Richest & 29.1 & 7038 & 31.4 & 10.5 & 1003 & 11.2 & 26.9 \\
\hline Total & 100 & 7375 & 100 & 100 & $\mathrm{xxx}$ & 100 & 100 \\
\hline
\end{tabular}

Note: Figures include both inpatient and outpatient visits

Source: Adams (2005, p.9)

Table 1. The Impact of Social Protection Strategies on Poverty Rate for each Country

\begin{tabular}{lcccc}
\hline & SPHE & HCE & SSE & GDP \\
\hline INDONESIA & -0.271626 & -0.196407 & -0.06942 & $-0.006777 * *$ \\
PHILIPPINES & $(1.155)$ & $(0.244)$ & $(0.450)$ & $(0.004)$ \\
& -1.763337 & & & 0.003774 \\
THAILAND & $(2.404)$ & 0.479445 & -0.449955 & $(0.013)$ \\
& $-0.998596 * *$ & $(0.483)$ & $(0.554)$ & $-0.011429 * *$ \\
VIETNAM & $(0.260)$ & $-1.534069 * *$ & $-1.682651 * *$ & $(0.003)$ \\
& $(0.544)$ & $(0.515)$ & $(0.540)$ & $-0.075081 * *$ \\
\hline
\end{tabular}

$(* *)$ denote significance at 5\% level. Numbers between brackets denote the "standard error"

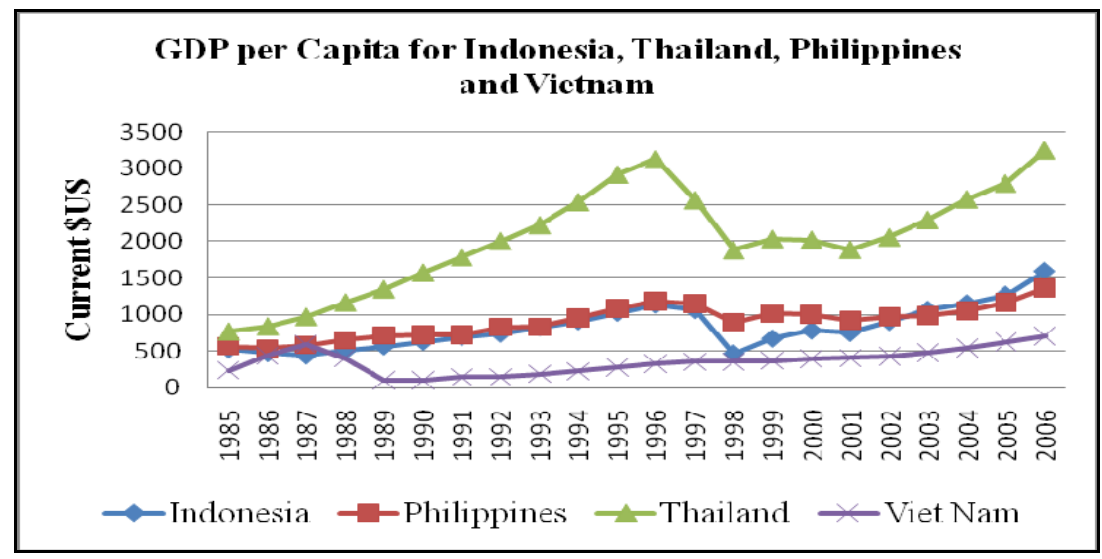

Figure 1. GDP Per Capita for the four Selected Southeast Asian Countries

Source: Earthtrends database (2010), accessed at: http://earthtrends.wri.org/searchable_db/index.php?theme=5 andvariable_ID $=638$ andaction $=$ select_countries 


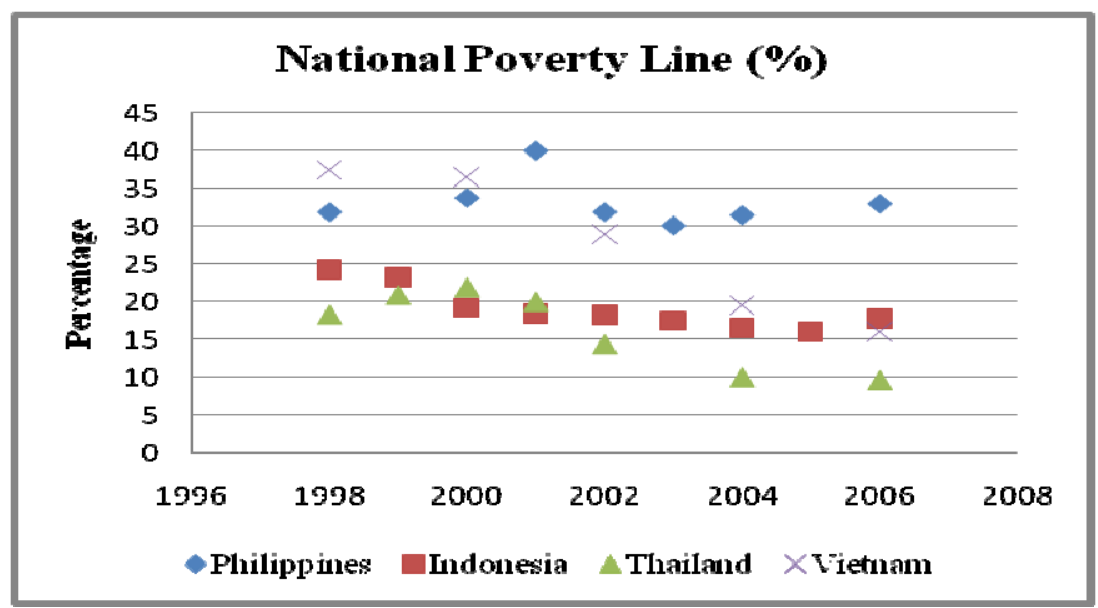

Figure 2. Poverty Line in Indonesia, Philippines, Thailand and Vietnam Source: National Economic and Social Development Board Thailand (2002, P.11); Basri (2010, P.5) Indonesia; ADB (2005, P.16); Warr (2005, p.15); Thang et al (2006, P.9); CIA database; UN database; Earthtrends database.

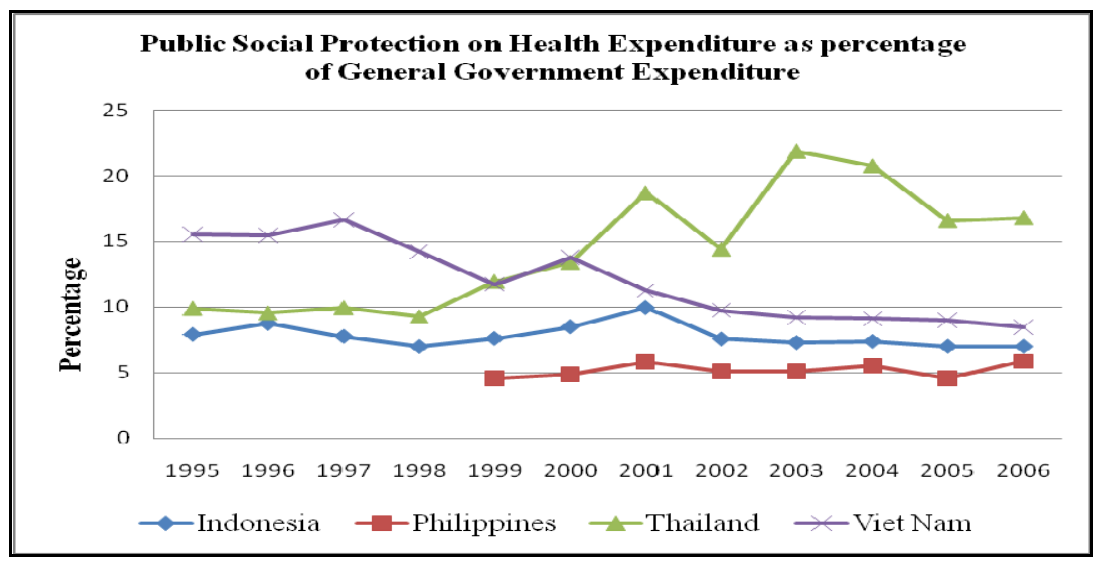

Figure 3. Social protection expenditure on health as a percentage of total government expenditure Source: ILO data base accessed at: http://www.ilo.org/dyn/sesame/IFPSES.SocialDBExp

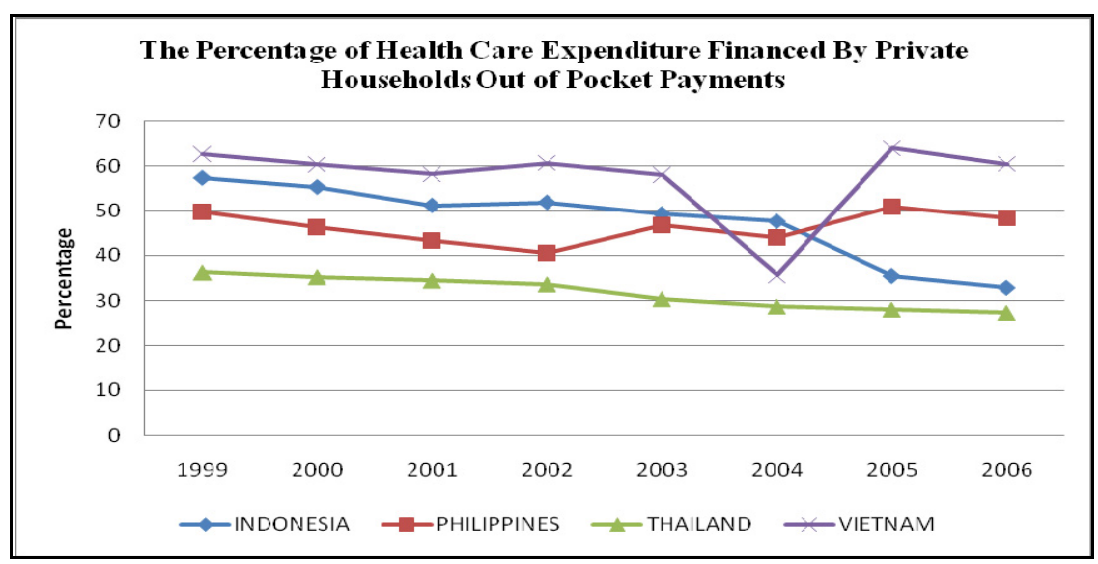

Figure 4. The Percentage of Health Care Expenditure Financed by Private Households out-of-pocket Payments Source: ILO data base accessed at: http://www.ilo.org/dyn/sesame/IFPSES.SocialDBExp 